\title{
Changes in Respiratory Activity during Encystment of Azotobacter vinelandii
}

\author{
By A. M. STOCK ALL (NÉE FIELD) AND C. EDWARDS* \\ Department of Microbiology, Life Sciences Building, The University, PO Box 147, \\ Liverpool L69 $3 B X, U K$
}

(Received 15 Octoher 1984; revised 1 February 1985)

\begin{abstract}
Vegetative cells of Azotobacter vinelandii were induced to encyst in the presence of $\beta$ hydroxybutyrate. Although modal cell volume fluctuated (2.7 to $\left.4 \mu \mathrm{m}^{3}\right)$ markedly during exponential growth, the final modal volume attained by mature cysts $\left(1.13\right.$ to $\left.1.3 \mu \mathrm{m}^{3}\right)$ was relatively constant. Respiratory activity of encysting cultures fell rapidly $3 \mathrm{~h}$ after initiation of encystment. This was accompanied by decreased inhibition of respiration by KCN. NADH oxidase activity of membrane preparations fell from approximately 450 to $50 \mathrm{nmol} \mathrm{O}_{2}$ consumed $\min ^{-1}$ (mg protein $)^{-1}$ during differentiation and was also less sensitive to $\mathrm{KCN}$. Difference spectra of cytochromes in membrane preparations revealed a number of changes. Amounts of cytochromes $b, c$ and $a_{1}$ all fell during encystment; cytochrome $o$ levels increased whilst cytochrome oxidase $d$ was gradually lost from the membrane during the first $22 \mathrm{~h}$ of morphogenesis.
\end{abstract}

\section{INTRODUCTION}

Vegetative cells of Azotobacter vinelandii can be induced to encyst in the presence of $\beta$ hydroxybutyrate as the sole carbon source. The process occurs in approximately $65 \mathrm{~h}$ at $30^{\circ} \mathrm{C}$ (Socolofsky \& Wyss, 1961 ; Lin \& Sadoff, 1968). During this period of differentiation motile cells lose their flagella, round up and secrete membrane-like vesicles into the capsular material to form a dense shingled structure called the exine. This encloses a less dense intine layer and the cyst central body. The cysts are spherical, metabolically dormant, refractile and more resistant to deleterious physical and chemical changes than are the cells (Sadoff, 1975). Enzyme activity, structural development and lipid composition have all been investigated during encystment (Hitchins \& Sadoff, 1970, 1973; Reusch \& Sadoff, 1979, 1981). Changes in lipid composition have been particularly well characterized. A major feature is that the phospholipids of the cell membrane are replaced by a family of 5 -n-alkyl resorcinols and 6 -n-alkyl pyrones during encystment. These novel lipids are synthesized from $8 \mathrm{~h}$ after the induction of encystment and it has been proposed that they may form a unique membrane matrix which contributes to the physiology and properties of the cyst (Reusch \& Sadoff, 1983).

Recently, we have shown that there are significant differences between vegetative cells and cysts with respect to respiratory enzyme activities, cytochrome content and extent of inhibition of respiration by $\mathrm{KCN}$. The respiratory activity of cysts is some 10 -fold lower and cytochrome oxidase $d$ is apparently absent. Respiration of cysts is also much less sensitive to KCN (Field \& Edwards, 1983). In this paper we examine the time course of changes in respiratory activity during encystment. Complex modulation of respiration, sensitivity to $\mathrm{KCN}$ and cytochrome content are revealed. These changes are discussed in relation to other known temporal events that occur after induction of encystment.

\section{METHODS}

Growth and maintenance of the bacteria. Azotobacter vinelandii (NCIB 8789) was grown in a $\mathrm{N}$-free medium that contained, per litre: $\mathrm{Na}_{2} \mathrm{HPO}_{4}, 0.82 \mathrm{~g} ; \mathrm{KH}_{2} \mathrm{PO}_{4}, 0.86 \mathrm{~g} ; \mathrm{MgSO}_{4} .7 \mathrm{H}_{2} \mathrm{O}, 0.2 \mathrm{~g} ; \mathrm{CaCl}_{2}, 50 \mathrm{mg} ; \mathrm{Na}_{2} \mathrm{MoO}_{4}, 5 \mathrm{mg}$; nitrilotriacetic acid, $1 \mathrm{mg}$; $\mathrm{FeSO}_{4}, 7 \mathrm{H}_{2} \mathrm{O}, 11 \mathrm{mg}$; citric acid, $10 \mathrm{mg}$; mannitol, $15 \mathrm{~g}$. Cultures were maintained on 
plates of Lab M (Pendleton, Salford, UK) agar made up to $1 \%(w / v)$ with the $\mathrm{N}$-free medium. Batch cultures were grown in $400 \mathrm{ml}$ growth medium in 2 litre flasks with shaking at $30^{\circ} \mathrm{C}$. Large-scale cultivation was in $4-6$ litre amounts using a Churchill fermenter (L.H. Engineering, Stoke Poges, Bucks) at a stirring rate of 200 r.p.m. and aeration of 1 litre air $\mathrm{min}^{-1}(1 \text { culture })^{-1}$. Growth was followed either by measuring the $\mathrm{OD}_{550}$ with a CE 272 spectrophotometer (Cecil Instruments Cambridge), or by counting cell numbers of culture samples appropriately diluted in Isoton 11 with a ZBI Coulter counter (Coulter Electronics, Harpenden, Herts). Cell volumes were measured with a C-1000 channelyzer linked to the Coulter counter after calibration of the latter with latex beads of $1 \cdot 15 \mu \mathrm{m}$ diameter.

Induction of encystment. Exponentially-growing vegetative cells $\left(\mathrm{OD}_{550} 0 \cdot 6-0 \cdot 8\right)$ were pelleted by centrifugation at $17000 \mathrm{~g}$ for $20 \mathrm{~min}$ and washed once with sterile $20 \mathrm{~mm}$-potassium phosphate buffer, $\mathrm{pH} 7 \cdot 0$. The cells were finally resuspended in a volume equal to that of the original culture using growth medium that contained $0 \cdot 2 \%$ $(w / v) \beta$-hydroxybutyrate as the sole carbon source. Almost complete encystment occurred when these cells were incubated for $65 \mathrm{~h}$ with shaking at $30^{\circ} \mathrm{C}$.

Preparation of membranes. Cell or cyst suspensions were disrupted using a modification of the lytic system of Repaske (1958). Vegetative cells or cysts were suspended in $33 \mathrm{~mm}$-Tris/HCl buffer, pH 8, which contained EDTA $\left(133 \mu \mathrm{g} \mathrm{ml}^{-1}\right)$ and lysozyme $\left(33 \mu \mathrm{g} \mathrm{ml}^{-1}\right)$. After incubation for $10 \mathrm{~min}$ with occasional stirring the suspension was sonicated at a setting of $12 \mu \mathrm{m}$ for $3 \times 1$ min periods with an MSE ultrasonic disintegrator. Unbroken cells and debris were removed by centrifugation at $17000 \mathrm{~g}$ for $20 \mathrm{~min}$. Membranes were sedimented from the resultant supernatant by centrifugation at $180000 \mathrm{~g}$ for $1 \mathrm{~h}$ at $4{ }^{\circ} \mathrm{C}$. The pellets were resuspended in $20 \mathrm{~mm}$-phosphate buffer, $\mathrm{pH} 7 \cdot 0$, and these membrane preparations used immediately.

Measurements of oxygen uptake. Oxygen uptake rates by cell suspensions during encystment were measured at $30^{\circ} \mathrm{C}$ with a Rank oxygen electrode (Rank Bros., Bottisham, Cambridge, UK) linked to an MSE Vitatron chart recorder.

Cytochrome content. Changes in amounts of cytochromes during encystment were detected from difference spectra of membrane preparations in $2 \times 1 \mathrm{ml}$ matched glass cuvettes of $0.5 \mathrm{~cm}$ path length. Spectra were plotted at room temperature on an SP1800 spectrophotometer. Reduction was by the addition of a few grains of sodium dithionite to one cuvette and oxidation by vigorously shaking the contents of the other cuvette. For CO-difference spectra, both cuvettes were reduced, and $\mathrm{CO}$ bubbled through the contents of one cuvette for $5 \mathrm{~min}$. The reducedplus- $\mathrm{CO}$ minus reduced difference spectrum was then recorded. Cytochromes were quantified using the following mM absorption coefficients (wavelength pairs are in parentheses): $a_{1}, 4 \cdot 6(603-575) ; b, 17 \cdot 5(560-570) ; c_{4}+c_{5}$, $17.5(553-538) ; d, 8.5(630-655) ; o, 170(418-390)$.

Determination of extracellular polysaccharide and dry weight. Exopolysaccharide production during exponential growth was measured by the alcohol precipitation method of Jarman et al. (1978). Samples (40 ml) were removed at intervals from a batch culture (4 l) and $5 \mathrm{M}-\mathrm{NaCl}$ and $0.5 \mathrm{M}$-EDTA $(0.8 \mathrm{ml}$ of each) added. After centrifugation at $24000 \mathrm{~g}$ for $40 \mathrm{~min}$ at $4{ }^{\circ} \mathrm{C}$ the supernatant was removed and mixed vigorously with $75 \mathrm{ml}$ propan-2-ol for $30 \mathrm{~s}$. After standing for $10 \mathrm{~min}$ at room temperature the resultant precipitate was filtered on to a Whatman GF/A filter which had been dried overnight at $110^{\circ} \mathrm{C}$ and weighed prior to use. The precipitate was washed on the filter with $100 \mathrm{ml}$ propan-2-ol/ $\mathrm{H}_{2} \mathrm{O}(3: 1$, by vol. $)$, dried and weighed to give the weight of extracellular polysaccharide in $40 \mathrm{ml}$ culture. The cell pellet from the first centrifugation step was washed in water, pelleted at $24000 \mathrm{~g}$ for $20 \mathrm{~min}$, resuspended in distilled water $(2 \mathrm{ml})$ and transferred to a dried preweighed glass vial. The suspension was dried overnight at $110^{\circ} \mathrm{C}$ and the vial weighed to yield the dry weight of cells from $40 \mathrm{ml}$ culture.

\section{RESULTS}

\section{Changes in modal cell volume during vegetative growth and ency'stment}

Experiments to investigate changes in volume during differentiation of cells into cysts revealed great variability in the modal cell volume of exponentially-growing vegetative cells. The results of a typical experiment are shown in Fig. 1. After inoculation of cells from the late exponential phase into growth medium, modal cell volume rose from $2 \cdot 3 \mu \mathrm{m}^{3}$ at $1 \mathrm{~h}$ to $3.2 \mu \mathrm{m}^{3}$ at $4 \mathrm{~h}$ and then gradually fell to $2.4 \mu \mathrm{m}^{3}$ at $8 \mathrm{~h}$. During this time $\mathrm{OD}_{550}$, cell numbers and dry weight all increased at similar rates (doubling time $180 \mathrm{~min}$ ) indicating that balanced growth (Campbell, 1957) was occurring. The fluctuation in volume must have been due to another factor(s). One possibility is that the extracellular polysaccharide alginic acid produced by $A$. vinelandii (Gorin \& Spencer, 1966) affects the measurements of cell volume. However, during vegetative growth this polymer was produced continuously but at a lower rate than the increase in cell numbers and therefore did not contribute to the changes in cell volume (Fig. 1). A similar result was obtained for cells grown in the presence of $\mathrm{NH}_{4} \mathrm{Cl}$, in which no cell volume changes can be detected during exponential growth. 

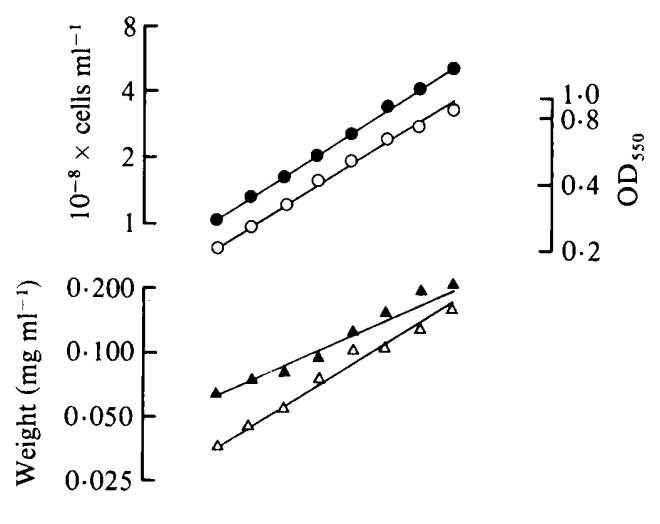

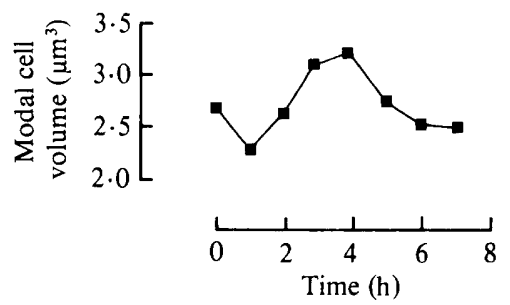

Fig. 1

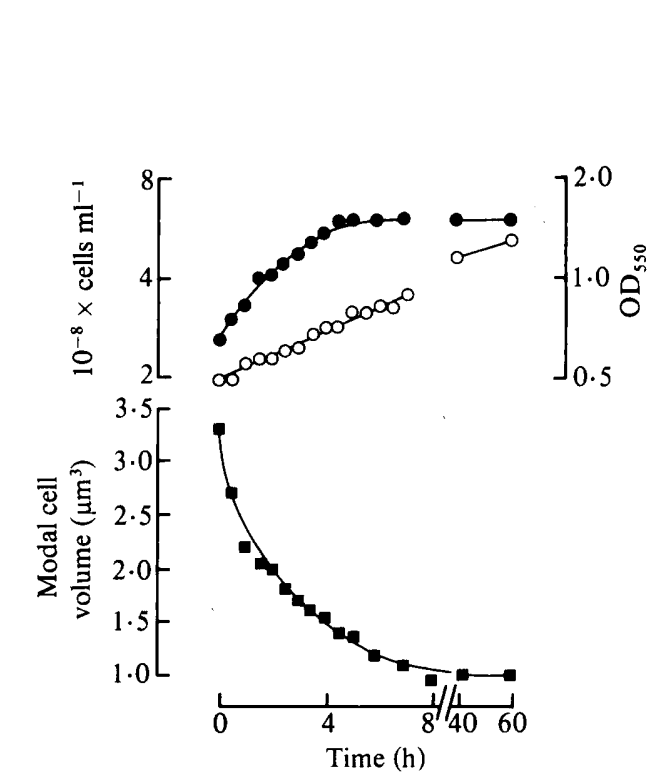

Fig. 2

Fig. 1. Changes in modal cell volume and exopolysaccharide production during exponential growth of A. vinelandii. Exponentially-growing cells were inoculated into growth medium that contained mannitol as the carbon source, and samples were removed from the culture at time intervals for the determination of cell numbers $(\bigcirc), \mathrm{OD}_{550}(\mathrm{O})$, exopolysaccharide production $(\boldsymbol{\Delta})$, cell dry weight $(\Delta)$ and modal cell volume ( $\square$ ). Results are from a typical experiment.

Fig. 2. Changes in modal cell volume and cell numbers after the induction of encystment of vegetative cells of $A$. vinelandii. Washed vegetative cells were inoculated into growth medium (at time 0 ) that contained $\beta$-hydroxybutyrate as the sole carbon source. Cell numbers $(O), \mathrm{OD}_{550}(O)$ and modal cell volumes $(\boldsymbol{Q})$ were measured during the subsequent period of differentiation. Results are from a typical experiment.

Table 1. Cell division and decrease in volume of $A$. vinelandii during encystment

Experimental details were as described for Fig. 2. Results are from a typical experiment.

\begin{tabular}{|c|c|c|c|c|c|}
\hline \multicolumn{3}{|c|}{$10^{-8} \times$ Cell numbers $\mathrm{ml}^{-1}$} & \multicolumn{3}{|c|}{ Modal cell volume $\left(\mu \mathrm{m}^{3}\right)$} \\
\hline $\begin{array}{c}\text { At } \\
\text { induction }\end{array}$ & $\begin{array}{c}\text { After } \\
\text { encystment }\end{array}$ & $\begin{array}{l}\text { Factor of } \\
\text { increase }\end{array}$ & $\begin{array}{c}\text { At } \\
\text { induction }\end{array}$ & $\begin{array}{c}\text { After } \\
\text { encystment }\end{array}$ & $\begin{array}{l}\text { Factor of } \\
\text { decrease }\end{array}$ \\
\hline $2 \cdot 36$ & $3 \cdot 85$ & 1.63 & $2 \cdot 70$ & $1 \cdot 28$ & $2 \cdot 11$ \\
\hline 1.63 & 3.75 & $2 \cdot 30$ & $3 \cdot 30$ & 1.28 & $2 \cdot 58$ \\
\hline $1 \cdot 52$ & $6 \cdot 15$ & $4 \cdot 05$ & 3.98 & $1 \cdot 13$ & $3 \cdot 52$ \\
\hline
\end{tabular}

The relationship between the initial cell volume and final cyst volume was investigated by inducing different batch cultures, each of which contained cells of a known modal volume, to encyst (Table 1). The final volume of mature cysts $\left(1 \cdot 13-1 \cdot 28 \mu \mathrm{m}^{3}\right)$ was similar irrespective of the initial volume of encysting cells. Exposure of cells to $\beta$-hydroxybutyrate resulted in cell division sufficient to attain the volume characteristic of cysts. Therefore some cells divided more than once before they developed into mature cysts and the number of divisions was related to the modal volume of the induced vegetative cells.

Changes in cell numbers, $\mathrm{OD}_{550}$ and modal volume during encystment are shown in Fig. 2. In this experiment cell numbers rose from $2.6 \times 10^{8}$ cells ml ${ }^{-1}$ to $6 \times 10^{8}$ cells ml ${ }^{-1}$ after $5 \mathrm{~h}$. The $\mathrm{OD}_{550}$ rose continuously (doubling time approximately $8 \mathrm{~h}$ ) from 0.5 to 0.9 after $8 \mathrm{~h}$ and gradually increased to $1 \cdot 3$ after $60 \mathrm{~h}$, presumably reflecting the increased refractility of cysts. 


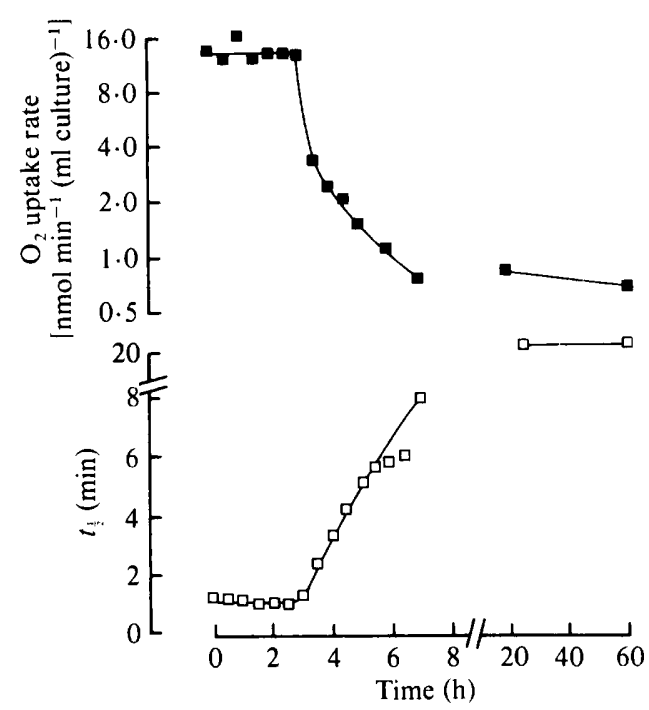

Fig. 3. Respiratory activity and changes in cyanide sensitivity during encystment. Samples ( $2.4 \mathrm{ml})$ were removed at intervals from an encysting culture of $A$. vinelandii and transferred directly to the chamber of an oxygen electrode. The oxygen uptake rate $(\square)$ was determined for each and $\mathrm{KCN}$ at a concentration $(0.1 \mathrm{mM})$ sufficient to inhibit the respiration of vegetative cells by $50 \%$ was then added. A $t_{2}$ value $(\square)$ was calculated by determining the time taken for this concentration of inhibitor to reduce the respiration rate to half of its initial value. Results are from a typical experiment.

Modal volume decreased rapidly from $3.33 \mu \mathrm{m}^{3}$ to $1 \cdot 13 \mu \mathrm{m}^{3}$ after $7 \mathrm{~h}$ and remained at this level for $60 \mathrm{~h}$, by which time mature cysts had been formed. The rapid drop in modal volume occurred concomitantly with the steepest rise in cell numbers.

\section{Oxygen uptake and the effects of cyanide during encystment}

We have shown previously that the respiratory activity of cysts is much lower than that of cells and is much more resistant to KCN (Field \& Edwards, 1983). The time course of modulation of terminal respiration was therefore investigated during encystment. Cyanide, at a concentration $(0.1 \mathrm{~mm})$ sufficient to inhibit the respiration of vegetative cells by $50 \%$ was added to samples removed at different stages of encystment. The time taken to inhibit respiration by $50 \%$ increased during differentiation. In order to compare the effects of the inhibitor at different times of encystment a $t_{\frac{1}{2}}$ value (time taken to reduce oxygen uptake to $50 \%$ of the untreated value) for inhibition of respiration by $0.1 \mathrm{~mm}-\mathrm{KCN}$ was calculated for each sample. Both respiration rate and $t_{\frac{1}{t}}$ remained constant up to $3 \mathrm{~h}$ after induction of encystment (Fig. 3). Thereafter, oxygen uptake rates fell rapidly from approximately 12 to $0.75 \mathrm{nmol} \mathrm{O}_{2}$ consumed $\min ^{-1}\left(10^{8} \text { cells }\right)^{-1}$ after $8 \mathrm{~h}$. The uptake rate remained at the latter value for the remainder of the differentiation period and is characteristic of mature cysts. The $t_{i}$ value rose from approximately $1 \mathrm{~min}$ at $3 \mathrm{~h}$ post-induction to $8 \mathrm{~min}$ by $8 \mathrm{~h}$, indicating the gradual acquisition of resistance to cyanide during the early stages of morphogenesis. The final $t_{\ddagger}$ value for mature cysts was $20 \mathrm{~min}$.

\section{Effects of cyanide on NADH oxidation by membrane preparations}

The increasing resistance of encysting cells to $\mathrm{KCN}$ could reflect decreasing permeability to the inhibitor due to reorganization of surface layers (see Sadoff, 1975). Therefore the activity of NADH oxidase in membrane preparations was measured in the presence and absence of KCN at different times of encystment. NADH oxidase activity $\left(\mathrm{nmol} \mathrm{O}_{2} \mathrm{~min}^{-1} \mathrm{mg} \mathrm{protein}^{-1}\right.$ ) remained constant at 450 up to $4 \mathrm{~h}$ after induction. Thereafter it fell rapidly to reach a value of 75 at $24 \mathrm{~h}$ and 50 at $60 \mathrm{~h}$ (Fig. 4). The latter value is characteristic of cyst membranes. The $t_{\frac{1}{2}}$ value for inhibition of NADH oxidase by $200 \mu \mathrm{M}-\mathrm{KCN}$ (sufficient to inhibit oxidase activity in 


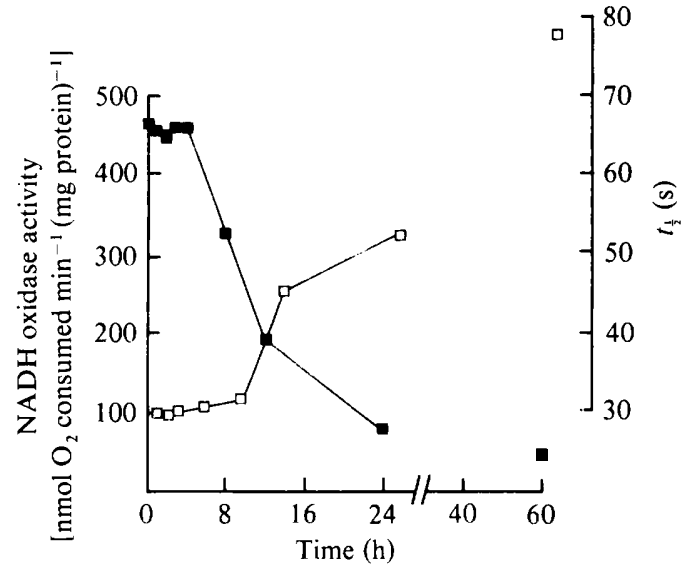

Fig. 4

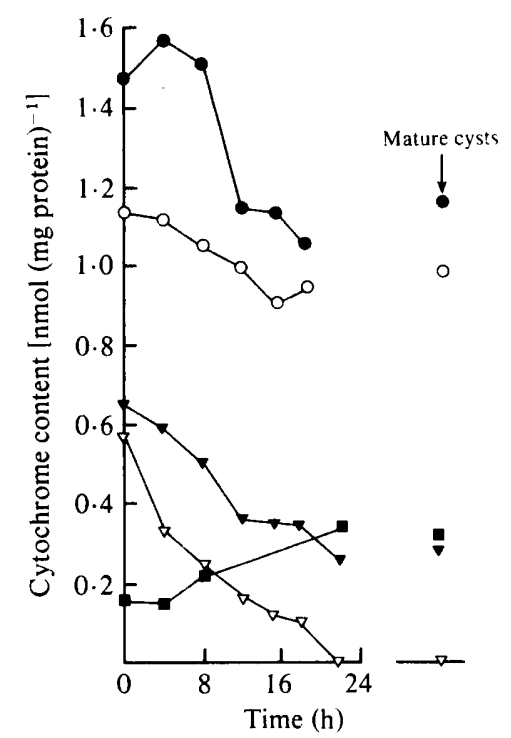

Fig. 5

Fig. 4. Respiratory activity and changes in cyanide sensitivity during oxidation of NADH by respiratory membranes prepared from samples removed at known times from an encysting culture. Oxygen uptake rates $(\square)$ by membrane preparations were measured in the presence of $50 \mathrm{~mm}-\mathrm{NADH}$. Cyanide $(200 \mu \mathrm{M})$, sufficient to inhibit NADH oxidation in membrane preparations from vegetative cells by $50 \%$, was then added. The $t_{\frac{1}{2}}$ value $(\square)$ was then calculated as in Fig. 4 . Results are from a typical experiment.

Fig. 5. Cytochrome levels during encystment. Culture samples were removed at time intervals during encystment and used to prepare membrane fractions. Difference spectra were plotted for each membrane sample and used to calculate the amount of total cytochrome $c(O)$; cytochrome $b(O)$; cytochrome $a_{1}(\boldsymbol{\nabla})$; cytochrome $d(\nabla)$ and cytochrome $o(\boldsymbol{\square})$. The cytochrome concentrations in mature cyst membranes are shown on the right (results from Field \& Edwards, 1983; means of five determinations)

vegetative cell membranes by $50 \%$ ) rose from $30 \mathrm{~s}$ at $8 \mathrm{~h}$ to approximately $76 \mathrm{~s}$ at $60 \mathrm{~h}$. This showed that the changes in sensitivity to $\mathrm{KCN}$ observed during encystment reflected membrane composition and activity rather than a permeability effect.

\section{Changes in cytochrome content during encystment}

Changes in respiratory activity during encystment were further characterized by measuring the concentrations of cytochromes from difference spectra of suspensions of cytoplasmic membranes. Cytochromes $b$ and $a_{1}$ decreased in amount during the first $20 \mathrm{~h}$ of encystment to reach approximately $80 \%$ and $40 \%$ respectively of the contents of vegetative cells. Thereafter the concentrations of these cytochromes remained constant during differentiation. Total cytochrome $c$ showed a slight increase in amount during the first $4 \mathrm{~h}$ of encystment but then fell to reach $72 \%$ of the initial value by $20 \mathrm{~h}$. Cytochrome $d$ decreased from $0.58 \mathrm{nmol} \mathrm{mg} \mathrm{protein}^{-1}$ to undetectable levels by $22 \mathrm{~h}$. In contrast, the concentration of cytochrome oxidase $o$ rose from $0.15 \mathrm{nmol} \mathrm{mg}$ protein ${ }^{-1}$ to $0.34 \mathrm{nmol} \mathrm{mg}$ protein $^{-1}$ (Fig. 5). Mean values (five determinations) taken from Field \& Edwards (1983) of the concentration of the cytochromes in membranes prepared from mature cysts are also shown in Fig. 5. These indicate that no further changes occur in cytochrome content after the initial $20-22 \mathrm{~h}$ of encystment.

\section{DISCUSSION}

The changes in modal volume that occur during exponential growth of vegetative cells of $A$. vinelandii are not due to the production of extracellular polysaccharide. They most likely reflect growth under $\mathrm{N}_{2}$-fixing conditions. Post et al. (1982) found that $\mathrm{N}_{2}$-fixing cells of $A$. vinelandii 


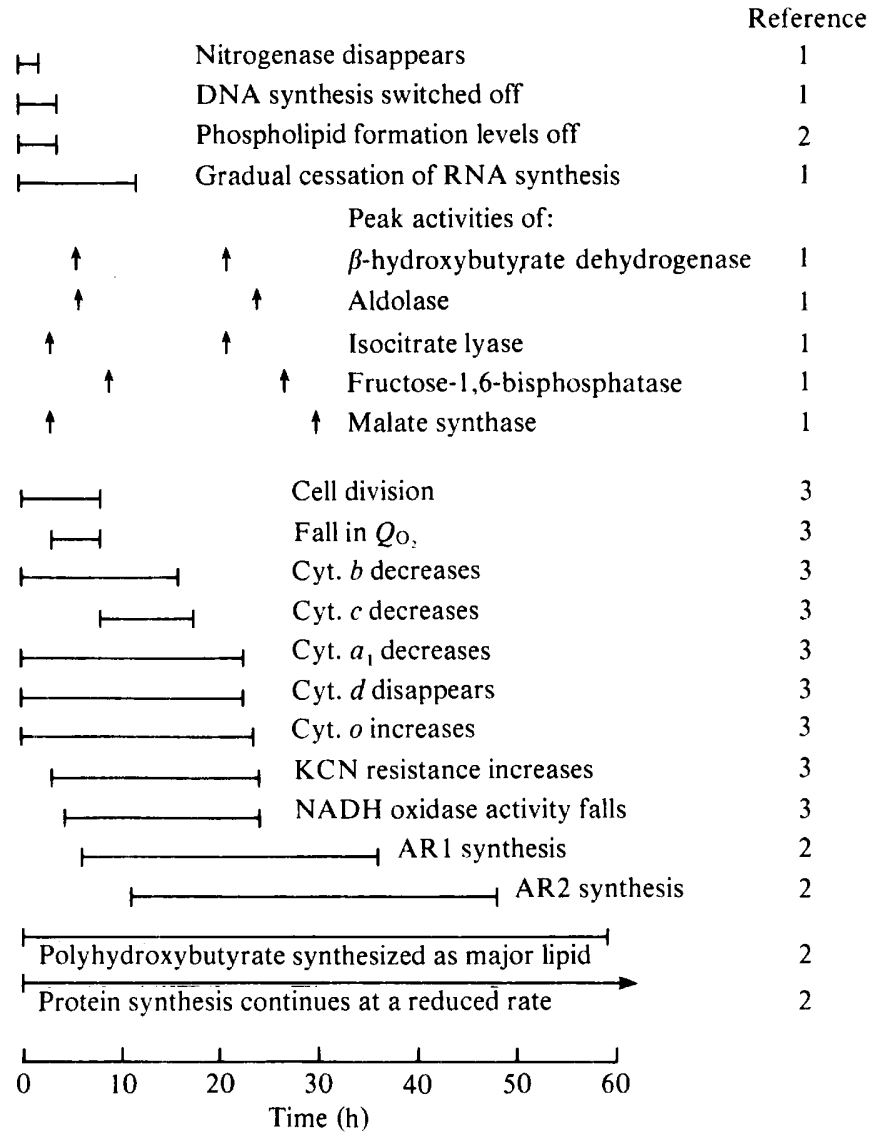

Fig. 6. Comparison of the time course of modulation of respiratory activity (this paper) with changes previously reported for other parameters during encystment. The references are as follows; 1 , Hitchins \& Sadoff (1973); 2, Reusch \& Sadoff (1981); 3, results from this work.

growing in continuous culture increased in volume in response to raised oxygen tensions. They proposed that this was due to an increase in the amount of intracytoplasmic membrane. Such a response could explain the results reported here. Table 1 shows that highest cell volumes were found at low culture densities and hence greater oxygen tensions. This view is supported by the fact that cells growing in the presence of $\mathrm{NH}_{4} \mathrm{Cl}$ as a nitrogen source (i.e. under non-fixing conditions) do not fluctuate in volume during exponential growth (unpublished observations).

The characteristic variations in modal cell volume have allowed us to examine the relationship between the volume of cells at induction and the final volume of mature cysts. Addition of $\beta$-hydroxybutyrate triggers off reductive cell division which results in successively smaller progeny until at $8 \mathrm{~h}$ the characteristic cyst volume of approximately $1.2 \mu \mathrm{m}^{3}$ is attained. Some cells divide more than once during this process, the number of divisions being related to the volume of cells at the commencement of encystment.

The timing of the various phases of respiratory activity reported here can be compared with previously published results for a number of other events which occur during encystment. Key metabolic enzymes fluctuate in activity and rise to peak values at characteristic times during encystment. For example $\beta$-hydroxybutyrate dehydrogenase, aldolase, isocitrate lyase, fructose1,6-bisphosphatase and malate synthase all have two maxima of activity during encystment (Fig. 6). Within $4 \mathrm{~h}$ of induction nitrogenase activity becomes undetectable, DNA synthesis is switched off and phospholipid formation levels off. Cell division continues up to $8 \mathrm{~h}$. 
Respiratory activity remains constant up to $3 \mathrm{~h}$ but thereafter declines rapidly. Presumably a high rate of oxygen consumption for respiratory protection of nitrogenase (Jones et al., 1973) is unnecessary because the activity of this enzyme has disappeared after approximately $2 \mathrm{~h}$. The rapid fall in respiratory activity is accompanied by increased resistance to $\mathrm{KCN}$ which suggests that changes in the terminal oxidases of the bacterium are occurring. This proposal is supported by the fact that whole cysts (unlike cells) yield biphasic curves for the inhibition of respiration by $\mathrm{KCN}$ and that $\mathrm{I}_{50}$ values for the inhibition of oxidation of NADH and NADPH by KCN in cyst membrane preparations are approximately 10 -fold higher than those recorded for membranes from vegetative cells (Field \& Edwards, 1983). From previous work on electron transport in $A$. vinelandii one might predict that increased resistance to cyanide could result from increased synthesis of cytochrome oxidase $d$ (Haddock \& Jones, 1977; Jurtshuk \& Yang, 1980). However, cytochrome $d$ is in fact lost during differentiation $(0-22 \mathrm{~h})$. The concentrations of cytochromes $b$, $c$ and $a_{1}$ also fall during this time, whereas the concentration of cytochrome oxidase $o$ rises. The possibility that increasing resistance to cyanide reflects changes in the permeability of the membrane to the inhibitor due to modulation of membrane lipid content is unlikely because the NADH oxidase activity of membrane preparations also falls and becomes less sensitive to inhibition by KCN. Taken together, these results can be interpreted in one of two ways. Firstly, modulation of respiratory activity and cyanide sensitivity is a consequence of changes in the terminal oxidases. Support for this comes from the knowledge that NADH oxidation proceeds principally via the $b \rightarrow d$ route (Hoffman et al., 1979, 1980a,b). Thus, loss of cytochrome $d$ might result in the gradual lowering of NADH oxidase activity. Increased sensitivity to cyanide is more difficult to explain. One possibility is the synthesis of a second type of cytochrome $o$ oxidase during encystment. This is a strong possibility because amounts of cytochrome $o$ increase significantly during encystment (Fig. 5). Two types of cytochrome $o$ differing in their sensitivity to KCN have been detected in $A$. vinelandii (Erickson \& Diehl, 1973; Jurtshuk \& Yang, 1980). Therefore, increased resistance of cysts to cyanide may be due in part either to increased amounts of this cyanide-insensitive $o$-type cytochrome oxidase or to an autooxidizable type $b$ cytochrome which has been proposed by Kauffman \& Van Gelder (1974) to mediate a third cyanide insensitive branch of the respiratory chain.

Secondly, it could be hypothesized that changes in respiratory activity occur as a result of the synthesis of novel membrane lipids. Phospholipid synthesis declines and levels off during the first $4 \mathrm{~h}$ of encystment, and shortly after this time the synthesis of alkyl resorcinols AR 1 and AR2 commences and continues up to approximately $36 \mathrm{~h}$ (AR1) and $48 \mathrm{~h}$ (AR2) post-induction. These lipids may alter the environment of respiratory proteins so drastically as to exclude cytochrome $d$, and change membrane structure and function sufficiently to dampen the activity of the respiratory chain. The novel lipids synthesized during the encystment of $A$. vinelandii would therefore be a major contributory factor to the metabolic dormancy of the cyst (Reusch \& Sadoff, 1983). Further work will concentrate on characterizing the cyanide insensitivity of cysts and attempting to distinguish alterations in membrane structure from those of function and activity.

We would like to thank the SERC for the award of a studentship to A.M.S.

\section{REFERENCES}

Campbell, A. C. (1957). Synchronization of cell division. Bacteriological Reviews 21, 263-272.

ERICKSON, S. R. \& Diehl, H. (1973). The terminal oxidases of Azotobacter vinelandii. Biochemical and Biophysical Research Conmunications 50, $321 \cdots 327$

Field, A. M. \& EDWARDS, C. (1983). Respiratory properties of cysts and vegetative cells of Azotobacter cinelandii. FEMS Microbiology Letters 20, 113-117.

Gorin, P. A. J. \& Spencer, J. F. T. (1966). Exocellular alginic acid from Azotobacter vinelandii. Canadian Journal of Biochemistry 44, 993-999.
HADDOCK, B. A. \& Jones, C. W. (1977). Bacterial respiration. Bacteriological Reviews 41, 47-99.

Hitchins, V. M. \& SadofF, H. L. (1970). Morphogenesis of cysts in Azotobacter vinelandii. Journal of Bacteriology' 104, 492-498.

Hitchins, V. M. \& SAdoff, H. L. (1973). Sequential metabolic events during encystment of Azotobacter vinelandii. Journal of Bacteriology 113, 1273-1279.

Hoffman, P. S., Morgan, T. V. \& Dervartanian, D. V. (1979). Respiratory-chain characteristics of mutants of Azotobacter vinelandii negative to tetra- 
methyl-p-phenylenediamine oxidase. European Journal of Biochemistry 100, 19-27.

Hoffman, P. S., Irwin, R. M., Carreira, L. A., Morgan, T. V., Ensley, B. D. \& Dervartanian, D. V. $(1980 a)$. Studies of photochemical action spectra on $N, N, N^{\prime}, N^{\prime}$-tetramethyl-p-phenylenediamine oxidase-negative mutants of Azotohacter vinelandii. European Journal of Biochemistry 105, 177 185.

Hoffman, P. S. Morgan, T. V. \& Dervartanian, D. V. (1980 b). Respiratory properties of cytochrome c-deficient mutants of Azotohacter vinelandii. European Journal of Biochemistry 110, 349.354.

Jarman, T. R., Deavin, L., Slocombe, S. \& RigheLATO, R. C. (1978). Investigation of the effect of environmental conditions on the rate of exopolysaccharide synthesis in Azotobacter vinelandii. Journal of General Microbiology 107, 59-64.

Jonfs, C. W., Brice, J. M., Wright, V. \& ACKRell, B. A. C. (1973). Respiratory protection of nitrogenase in Azotohacter vinelandii. FEBS Letters 29 , $77-80$.

JuRTSHUK, P. \& YANG, T. (1980). Oxygen reactive haemoprotein components in bacterial respiratory systems. In Diversity of Bacterial Respiratory Systems, vol. 1, pp. 137-159. Edited by C. J. Knowles. Boca Raton: CRC Press.

Kauffman, H. F. \& Van Gelder, B. F. (1974). The respiratory chain of Azotobacter vinelandii. III. The effect of cyanide in the presence of substrates. Biochimica et biophysica acta 333, 218-227.

LIN, L. P. \& SADOFF, H. L. (1968). Encystment and polymer production by Azotobacter vinelandii in the presence of $\beta$-hydroxybutyrate. Journa! of Bacteriology 95, 2336-2343.

Post, E., Golecki, J. R. \& Oelze, J. (1982). Morphological and ultrastructural variations in Azotobacter vinelandii growing in oxygen-controlled continuous culture. Archives of Microbiology 133, 7582.

REPASKE, R. (1958). Lysis of Gram-negative organisms and the role of versene. Biochimica et biophysica acta 30, 225-232.

REUSCH, R. N. \& SADOFF, H. L. (1979). 5-n-alkyl resorcinols from encysting Azotobacter vinelandii: isolation and characterization. Journal of Bacteriology 139, 448453.

REuSCH, R. N. \& SADOFF, H. L. (1981). Lipid metabolism during encystment of Azotobacter vinelandii. Journal of Bacteriology 145, 889-895.

ReusCh, R. N. \& SADOFF, H. L. (1983). Novel lipid components of the Azotobacter vinelandii cyst membrane. Nature, London 302, 268-270.

SADOFF, H. L. (1975). Encystment and germination in Azotobacter vinelandii. Bacteriological Reviews 39, 516-539.

SoColofsky, M. D. \& Wyss, O. (1961). Cysts of Azotobacter. Journal of Bacteriology 81, 946-954. 